\title{
SPOKECZEŃSTWO, KULTURA
}

\section{Krzysztof Gawlikowski}

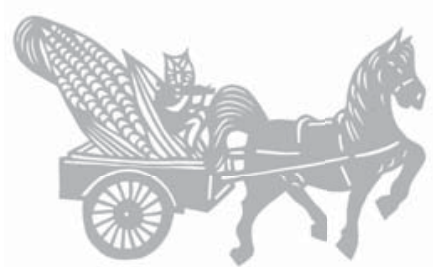

\section{ZAPISKI Z PAWILONU ODLATUJĄCEGO ŻURAWIA (III)}

Do Chin po raz pierwszy przyjechałem 30 września 1964 r. Specjalnie tak zaplanowałem tę podróż, by przybyć na 1 października, do kraju ustrojonego na święto narodowe. Już wtedy zauważyłem bowiem, że ze wszelkich podróży najbardziej wbija się nam w pamięć dzień przybycia i dzień odjazdu, podczas gdy to, co między nimi potem zlewa się w całość, a szczegóły ulegają zatarciu.

Był to okres, gdy - wraz z zaostrzaniem się sporu między Pekinem a Moskwą - ograniczano wszelkie kontakty Polski z Chinami. W 1964 r., po raz pierwszy po kilku latach - a jak się okazało potem i po raz ostatni w tym okresie - podpisano umowę o współpracy naukowej i kulturalnej między naszymi krajami, która przewidywała również wymianę studentów. Do Polski miało przyjechać 18 Chińczyków, ja zaś byłem jedynym kandydatem na wyjazd do Chin. Moje starania wspierał plik opinii i rekomendacji sławnych profesorów Uniwersytetu Warszawskiego i polityczne poparcie ZMS oraz ZSP. Byłem wtedy po czwartym roku psychologii i po trzecim sinologii. Rzecz jasna, nie istniały wtedy żadne możliwości pojechania do Chin prywatnie... Okazało się wkrótce, że był to ostatni już moment na taką podróż - niebawem Rewolucja Kulturalna miała zupełnie odciąć Chiny od świata i to na wiele lat. Późniejsze zaś zmiany radykalnie zmieniły obraz Chin. Tak więc udało mi się jeszcze zobaczyć resztki dawnych Chin i pooddychać ich atmosferą.

Zacznijmy od spraw najbardziej oczywistych. Stary Pekin otaczał wciąż mur $\mathrm{z}$ bramami miejskimi, jak w epoce cesarskiej. Teraz nie ma nie tylko muru ani bram, ale nie ma i tamtego miasta. Na miejscu sennej stolicy dawnych, wiejskich Chin, parterowych domków i wąskich zaułków, wyrosła super nowoczesna metropolia z tysiącami wielkich gmachów, szerokimi ulicami, estakadami, korkami tło- 
czących się samochodów i reklamami, bijącymi na każdym kroku w oczy..., prawie jak w Tokio, czy Los Angeles.

Kiedy ja przyjechałem tu po raz pierwszy, jeszcze widziałem wkraczające do miasta karawany objuczonych wielbłądów gdzieś z Azji Centralnej. Za popularny środek transportu towarowego służyła dwukołowa arba zaprzężona w woła, muła i osła biegnącego na przyprzążkę. Najczęściej jednak wszelkie ładunki przewoziły rowerowe riksze. Nawet słupy telegraficzne! Przejeżdżające samochody osobowe można było liczyć na palcach - woziły prawie wyłącznie wysokich funkcjonariuszy i korpus dyplomatyczny. Teraz riksze są tylko dla turystów, głównie zagranicznych, jako szczególna atrakcja, tak jak dorożki konne w Warszawie na Starym Mieście. Wtedy na postojach przy ważniejszych bramach stały ich dziesiątki, osobowych i towarowych, bo taksówki były niesłychanym luksusem, dostępnym właściwie tylko nielicznym cudzoziemcom. Teraz prawdziwą rikszę przewożącą jakiś towar da się czasem zobaczyć w nielicznych rejonach starego Pekinu, cudem jeszcze uchowanych. A dla zwierząt nie ma miejsca w duszącej się od samochodów metropolii, rozrosłej od tego czasu z dwu do dwunastu milionów mieszkańców.

W sklepach sprzedawano wtedy jeszcze małe buciki dla kobiet $\mathrm{z}$,lotosowymi stópkami”. Takie nóżki miało jeszcze bardzo wiele starszych pań. Ba, trafiały się i czterdziestolatki z bandażowanymi stópkami. Zimą - w czarno-granatowych watowanych kurtkach i spodniach, w czymś w rodzaju czarnego czepka na głowie, kusztykających na tych swoich „kopytkach”, w jasnych skarpetkach i czarnych, płóciennych pantofelkach. Dziś nie ma już staruszek z takimi nóżkami i dawną elegancją, pykających cienkie fajeczki z długim cybuchem.

Wśród pól trafiały się jeszcze małe świątynki. Zazwyczaj były zamknięte, ale przez szpary dało się zajrzeć do środka i zobaczyć zakurzone bóstwa. I wszędzie spotykało się zdobne, kamienne stele na grzbietach wielkich żółwi, głoszące w swych inskrypcjach chwałę dawnych mandarynów. Wśród pól pełno też było grobów, zwykłych kopczyków ziemnych, czy cmentarzyków znamienitych rodzin, z kamiennym wystrojem. Trafiały się i cmentarze klasztorne, z kamiennymi stupami i ołtarzami ofiarnymi.

Z tego świata, okalającego dawną stolicę, też nic już niemal nie zostało. Zmiotła go Rewolucja Kulturalna i kto wie, czy nie bardziej zachłanny od niej moloch wolnorynkowej urbanizacji. Resztki małej architektury kamiennej i fragmenty wystroju dawnych domów zbiera teraz specjalne muzeum, podobne do europejskich lapidariów gromadzących ułamki antyczne. Ale ja jeszcze to wszystko pamiętam jako wystrój codziennego życia. Kraj epoki Mao, na wpół tradycyjny, dzielić się zdaje dystans lat świetlnych od Chin współczesnych, z ich wielkimi metropoliami i rozbuchaną konsumpcją, sklepami firmowymi Diora i Gucci'ego, eleganckimi klubami nocnymi, ekskluzywnymi koncertami Pavarottiego i najznamienitszych orkiestr filharmonicznych świata. Dziś nazwy dawnych podpekińskich wsi noszą przystanki komunikacji miejskiej u stóp nowoczesnych hoteli, czy lśnią- 
cych szkłem budynków biurowych, w zatłoczonej samochodami i tłumem przechodniów metropolii.

W Warszawie symbolem upadku komunizmu stało się ulokowanie giełdy (wyświęconej, jak teraz przystało, przez biskupa), w gmachu dawnego Komitetu Centralnego partii, gdzie urzędowali niegdyś Gomułka i Gierek. W Pekinie takim symbolem nowych czasów stała się była rezydencja Kang Shenga, wszechwładnego szefa tajnych służb komunistycznych od lat dwudziestych aż do jego śmierci w 1975 r., przy którym sowiecki Beria wydaje się naiwnym dziecięciem. Urządzono w niej elegancką restaurację i ekskluzywny klub nocny z ,partyzanckim” wystrojem: skrzynkami po amunicji jako stolikami, kaburami z pistoletami i pasami $\mathrm{z}$ amunicją rozwieszonymi po ścianach. Oczywiście z rezydującymi tam nie mniej eleganckimi panienkami. Podobno początkowo za dodatkową opłatą klienci mogli skorzystać z sypialni Kang Shenga, lecz ostatecznie ją zlikwidowano. Grób jego zresztą usunięto z cmentarza zasłużonych. Czyż tryumf gospodarki rynkowej nad komunizmem nie znalazł w tym jeszcze bardziej drwiącego wyrazu?

Chiny, jakie widziałem w latach 60 ., były wciąż dawnym pre-industrialnym krajem, nie zmienionym wcale tak bardzo od czasów proklamowania Republiki w 1911 r., a ledwo nieco zmodernizowanym i zokcydentalizowanym, z warstwą komunistycznego, pół sowieckiego, sztafażu. Dawne Chiny trwały jednak nadal nie tylko na uliczkach handlowego Liulichangu, u bukinistów i antykwariuszy z manierami dawnych uczonych, w domostwach, ale i w ludziach, w ich ruchach, zachowaniu i obyczajowości. Rewolucja Kulturalna nie tylko zniszczyła wiele z materialnych świadectw przeszłości, obtłukła posążki przy świątyniach, czy zrujnowała je same, ona zdusiła i wyparła dawne Chiny z pamięci społecznej. A potem nastąpił fantastyczny skok cywilizacyjny epoki Denga do nowoczesnego świata, i zmiótł dawne Chiny niemal do reszty, razem z ich wiejsko-koszarowym komunizmem Mao. Dziś Chiny mogą się wydawać turystom wciąż jeszcze „egzotyczne", ale jest to egzotyka innego zupełnie rodzaju: azjatyckiej wersji w zasadzie nowoczesnego świata, podobna do tej z Hongkongu, Tokio, czy Bangkoku.

Warszawa dzisiejsza nie różni się zasadniczo od tej z epoki Gomułki. Tramwaj 15 chodzi nadal z tego samego Placu Narutowicza na Bielany, prawda, że bardzo rozbudowane. Jedzie tymi samymi ulicami, gdzieniegdzie z nowym budynkiem, częściej - z nowym wystrojem sklepów i z lepiej ubranymi ludźmi. Wszakże i wtedy były samochody prywatne, telefony w mieszkaniach, ba, nawet te same prywatne pawilony przy Świętokrzyskiej. Oczywiście, Polska zmodernizowała się nieco, ale człowiek, który ją opuścił dwadzieścia lat temu dzisiaj rozpozna bez trudu wszystkie niemal miejsca, gdyż będzie chodził tymi samymi ulicami, i po większej części wśród tych samych domów. W ciągu dwudziestu lat przybyły w Warszawie dwa mosty, ale obwodnicy jak nie było, tak nie ma.

Skala zmian w Chinach jest zupełnie nieporównywalna. Nie rzucając hasła „zbudowania drugiej Japonii” - prawie to uczyniono. Przybysz znający Chiny sprzed lat 
dwudziestu nie rozpozna większości ulic, bo zazwyczaj ich już nie ma, albo całe zostały przebudowane. Znajdzie wprawdzie te same nazwy miejsc, ale wyglądają one zupełnie inaczej. Oto przykład. Niedawno przyjechałem na kilka dni do Pekinu i umówiłem się z przyjaciółmi z Uniwersytetu Ludowego położonego na dalekich peryferiach, że będą na mnie czekali przy bramie uczelni. Gdy taksówkarz poinformował mnie, że jesteśmy na miejscu, zamiast okazałej bramy Uniwersytetu, otoczonej budkami i parterowymi pawilonami ze sklepikami i restauracjami, ujrzałem city wielkich hoteli, banków i biurowców. Zaczynam tłumaczyć kierowcy raz jeszcze, gdzie miał mnie dowieźć, a on pokazuje mi tę bramę, tyle że skrytą teraz między nowymi gigantycznymi gmachami. A byłem tam rok wcześniej i nic nie zapowiadało rozpoczęcia budowy. Teraz zaś nie widać już nawet śladu rusztowań. Wszystko funkcjonuje swoim rytmem. Podobnie jest nie tylko w wielkich miastach, ale i w miasteczkach powiatowych, we wsiach nawet. Całe niemal Chiny zbudowano na nowo, według innych standardów i wzorców. A społeczeństwo i jego życie zmieniły się chyba jeszcze bardziej. Nawet filmy o epoce Mao kręcone dzisiaj wyglądają sztucznie: nie sposób wytłumaczyć młodym aktorom i statystom, jak mają się ruszać i reagować. A ponadto są oni zbyt dobrze wykarmieni, czy wręcz pulchni! Dziś młodszy kolega chcący studiować historię tego mega-kraju musi dawne Chiny sobie wyobrazić, ja ich resztki jeszcze widziałem. Ale powróćmy jeszcze do samej podróży.

Jechałem do wymarzonych Chin pociągiem przez Syberię i Mongolię. Z Moskwy trwało to tydzień. Do Uralu, przypominającego nieco nasze Beskidy, jechaliśmy przez kraj zamieszkały i zagospodarowany, z dużymi miastami co kilka godzin. Potem jednak było już zupełnie inaczej. Pociąg zatrzymywał się na stacjach tylko dwa-trzy razy dziennie. Godzinami pędziliśmy przez ziemie bezludne, pustkowia i tajgę bez śladu człowieka. Przejeżdżaliśmy rzeki gigantyczne, z nabrzeżami zawalonymi jakimś starym chłamem. Wszystko jednak w Rosji porażało ogromem. I niemal wszystkie mijane miejsca, były mi znane ze starej, patriotycznej literatury. Dopiero jadąc przez Syberię zrozumiałem choćby w części szok, jaki przeżywali polscy zesłańcy i katorżnicy. Gdy wreszcie zatrzymywaliśmy się na jakiejś stacyjce, po sześciu, czy ośmiu godzinach jazdy, i to na kwadrans, albo nawet i dwadzieścia minut, nierzadko była to ledwo wioska na dziesięć chałup, którą można było całą obejść podczas postoju. Zapamiętałem sklepik z takiej osady: na ladzie leżała prostokątna bryła marmolady z wbitym nożem, obok stała skrzynka z gwoździami, była też beczka ze śledziami, sól i trochę zakurzonych konserw rybnych na półce. Była jeszcze nafta nalewana z dziwnej bańki. Jeśli pamiętać, że był to pewnie jedyny sklep w promieniu kilkuset kilometrów - stanie się oczywistą przeraźliwa mizeria tamtejszego bytowania.

Ludzie za to byli niezmiernie sympatyczni. Pasażerowie dosiadający się po drodze i po jednym, czy dwu dniach jazdy wysiadający gdzieś na pustkowiu - podróżowali z całymi zapasami chleba, sadła, wędzonych kawałków tłustej wieprzowiny, 
solonych ogórków i grzybów. Częstowali tym wszystkim wręcz uparcie i wylewnie opowiadali o swym życiu, celu podróży, rodzinach... Nowa twarz podróżnego, w dodatku inostranca, była dla nich ogromną atrakcją.

Najcudowniejszy, bajeczny zupełnie był Bajkał wokół którego jechaliśmy przez pół dnia. Samo jezioro było granatowo-zielone, nad nim prześwietlone słońcem, złociste, jesienne brzozy, a wszystko otaczały góry pokryte już świeżo spadłym śniegiem, aż iskrzące się bielą. Babuszki sprzedawały suszone ryby bajkalskie dodając szczególnego kolorytu życia codziennego do tego aż niewyobrażalnego dzikiego piękna jeziora.

Od Bajkału na południowy wschód wjechaliśmy już w ziemie ludów mongolskich, najpierw sowieckich Burjatów, a potem Mongolii właściwej. Skaliste góry, pofalowane pagórki, jakaś rdzawa ziemia i czerwonawy step zrudziałych już traw. W bladobłękitnym niebie wisiały orły polujące na gryzonie. Po kilkanaście w zasięgu wzroku. Czasem stado owiec, koni i wielbłądów, czy gromadka białych jurt pod wzgórzem. Stacyjki „sowieckiego typu” w postaci jednego, czy dwu domków, aż nierealnych w tym stepie, były jednak w stanie zupełnej rujnacji, choć jacyś kolejarze tam przecież dyżurowali (chyba?). Do mieszkania służyła im stojąca w pobliżu jurta. Było oczywiste, że każdą cegłę, belkę, gwóźdź, czy szybę do okna „europejskiego domu” trzeba tu było przywieźć z odległości tysięcy kilometrów. Dlatego jeśli jedna szyba się stłukła po zbudowaniu domku, nikt już nie umiał wstawić nowej, zresztą i szyby też nie było. I tak ze wszystkim. Na stacyjkach - Mongołowie, często w tradycyjnych strojach i na koniach. Nie dlatego, by gdzieś jechali, czy na kogoś oczekiwali, lecz po prostu celebrujący przyjazd pociągu jako lokalne wydarzenie i okazję do spotkania znajomych. Pamiętajmy, że pociąg pojawiał się tam wtedy dwa razy na tydzień.

W mongolskim wagonie restauracyjnym, gdy do niego wszedłem, zauważyłem w oszklonej szafce na paterze jabłka i równie zielone pomidory wymieszane razem. Wydawały się w tym pejzażu rudego stepu przelatującego za oknem tak egzotyczne, jakby zostały przywiezione $\mathrm{z}$ innej planety. Byłem zresztą $\mathrm{w}$ tym wagonie jedynym gościem, choć w pociągu kłębił się tłum młodych Chińczyków z tobołami. Później, już w Pekinie, dowiedziałem się, że byłem świadkiem exodusu Chińczyków z Mongolii. W związku z zaostrzającym się sporem sowiecko-chińskim odsyłano robotników pracujących przy wspólnych projektach, a nawet Chińczyków mieszkających w Ułan Bator od kilku pokoleń, uprawiających tam warzywa, czy zajmujących się rzemiosłem. Gdy moim współtowarzyszom podróży zakomunikowałem (trochę porozumiewałem się z nimi - przy pomocy słownika), że udaję się na obiad do mongolskiego wagonu, popatrzyli na mnie jak na samobójcę, a po powrocie wyraźnie oczekiwali na marne skutki pytając natarczywie co kwadrans, czy jeszcze nie muszę iść do toalety. Najwyraźniej sami nigdy nie zaryzykowali skosztowania jadła „dzikich Mongołów”. 
Niemal przez cały dzień jechaliśmy przez Pustynię Gobi. Nigdy nie wyobrażałem sobie, że pustynia może być tak cudownie piękna. Był to bowiem płaskowyż - kamienisty bardziej niż piaszczysty - porośnięty rozmaitymi suchoroślami o delikatnych, pastelowych barwach i najrozmaitszych kształtach. Srebrzyste, żółtawe, ametystowe, zielonkawe, wymieszane przedziwnie... Bajeczne, jak na dnie morza. I znowu bezmierne pustkowie.

Gdy stanęliśmy wreszcie na pogranicznej stacyjce chińskiej był wieczór. Zieleń drzew, wśród nich znajome wierzby i topole, kwitnące dalie, kanny, lwiepaszcze, zupełnie jak latem w Polsce. Jedyną różnicę stanowiły grające cykady, u nas nieobecne. Po latach miały mi często towarzyszyć we Włoszech. Porozwieszane kolorowe lampiony i różnobarwne chorągiewki. Pełno ludzi. Miałem dziwne wrażenie, że powróciłem do świata takiego jak nasz, choć nieco innego, znowu gęsto zamieszkałego i uczłowieczonego przez pokolenia. Krainy dzikich bezludzi wypełniające centralne obszary Eurazji pozostały za nami.

Poznany w pociągu Chińczyk towarzyszył mi do przyczepionego teraz chińskiego wagony restauracyjnego. Bez jego pomocy pewnie bym się do niego nie dostał. Pchali się tu bowiem wszyscy, wyposzczeni w Mongolii. Zapamiętałem jedną potrawę jako koszmar: trepangi z kurczakiem. Ja, jeden jedyny Europejczyk, usiłujący jeść pałeczkami, wówczas jeszcze niezbyt wprawnie. Trepangi, śliskie jak ślimaki, i ciągle wymykające się pałeczkom, a pociąg trzęsie i trzęsie... We mnie zaś wpatrują się wszystkie oczy.

Przez Chiny północne jechaliśmy aż do następnego wieczora. Uderzyło mnie, że wszystko było tam żółto-szare: ziemia, chaty i murki obejść chłopskich z ubitego lessu, dzieciaki utytłane w ziemi, często z gołymi pupkami, susząca się kukurydza, i pola dojrzewającego kaoliangu, wysokiego jak ona, tyle, że z kasztanowatymi wiechami ziarna na szczycie. Nawet dziwnie popodcinane drzewka przy drogach osypane kurzem lessowym były zielonawo-żółte, a blado błękitne niebo też wydawało się przesłonięte żółtawą mgiełką. Uznanie barwy żółtej za kolor Krainy Środka w prastarym systemie Pięciu Elementów nie było więc przypadkowe!

O zmierzchu pociąg powoli dojechał do murów stolicy. Zabrano mnie z dworca do szkoły: Pekińskiego Instytutu Języków. Specjalnie otwarto dla mnie już zamkniętą stołówkę, bym coś zjadł. Rozlokowałem się jakoś w swoim pokoju i rozejrzałem po domu studenckim. Przywitałem się z rozśpiewanymi Kubańczykami, którzy bawili się przy otwartych drzwiach. I padłem na łóżko, półprzytomny po tygodniu trzęsienia $\mathrm{w}$ pociągu.

Rano pojechaliśmy na Plac Tiananmen, na trybuny dla gości zagranicznych. W owych czasach cudzoziemców w Pekinie nie było wielu, a studentów cudzoziemskich - poza dość licznymi grupami Koreańczyków z Północy, Wietnamczyków z Północy i oddzielonego wtedy jeszcze Południa, jak też z Japonii - niewielu chyba ponad stu. Kraje zachodnie wciąż bojkotowały ChRL, traktowano zatem nas, studentów z Europy, Azji, Afryki i Ameryki Łacińskiej, jako „szanownych go- 
ści zagranicznych", których obecność jakoś symbolicznie nobilitowała Chiny i potwierdzała szacunek dla nich w świecie. W samym Pekinie co najwyżej oglądano się za „,białym cudzoziemcem”, ale już w podpekińskich wioskach, gdy przejeżdżałem rowerem biegały za mną tabuny dzieciaków, krzyczących nie tylko: yang guizi laile! - Czort zamorski przybył!. Ale też: Chang bizi, chang bizi! - Długonosy, długonosy! Tak bowiem tradycyjnie nazywano „zachodniaków”. Innej tradycyjnej nazwy: pixiezi - „skórzane buty” już wtedy nie słyszałem. Może dlatego, że większość przywódców i wysokich dostojników chińskich nosiła już wówczas skórzane obuwie zachodniego typu? Z osób na najwyższym piedestale tylko Lin Biao, wówczas minister obrony, występował stale w tradycyjnych, chińskich, płóciennych pantoflach.

Jak rzadkim zjawiskiem byli wtedy w Chinach cudzoziemcy może świadczyć następujący incydent. Byłem z innymi studentami-cudzoziemcami ze szkoły na wycieczce w Tianjinie, największym porcie Północy. Nie dojeżdżając do miasta autobus nasz zatrzymał się - mieliśmy tu zwiedzić jakiś zabytek. Niezadługo oblegał nas już tłum parotysięczny. Wielu usiłowało nas choćby dotknąć. Na otaczających nas bezpośrednio napierały dalsze szeregi tych, którzy też nas chcieli zobaczyć. Sytuacja zaczęła się robić rozpaczliwa, gdyż groziło nam po prostu zatratowanie. Na szczęście na odsiecz pospieszyli policjanci, którzy pięściami i łokciami wyprowadzili nas z opresji do naszego autobusu. Stąd, aparatem uniesionym nad głową, zrobiłem kilka zdjęć tego zbiegowiska. Mam więc dowód. A zdarzyło się to nie gdzieś w odległym interiorze, ale w pobliżu dużego miasta portowego.

Wróćmy jednak do mojego pierwszego dnia w Pekinie. Na głównej trybunie widziałem wtedy Mao, po raz pierwszy i ostatni, choć z daleka. Byli tu też inni przywódcy;niektórych spotkałem potem z bliska przy rozmaitych okazjach. Znałem oczywiście z Polski komunistyczne pochody i manifestacje ,radosnej ludności”. Jednakże to, co zobaczyłem wtedy w Pekinie porażało swym ogromem. Już sam bezkresny Plac Tiananmen, mieszczący bez mała milion ludzi, wprawiał w osłupienie tym morzem głów. A przed nami, całą szerokością przeogromnej Alei Chang’an płynęła godzinami ludzka rzeka. Ze swymi czerwonymi hasłami, barwnymi chorągiewkami, najrozmaitszymi makietami. Jak się dowiedziałem nazajutrz przeszło wtedy w pochodzie dwa i pół miliona ludzi, a ja myślałem, że z dziesięć! Nigdy przecież w życiu nie widziałem miliona ludzi naraz i nie wyobrażałem sobie nawet ile to jest! Na zakończenie pod trybunę podbiegły tysiące dzieci stojących przedtem gdzieś głębiej na placu. Zaczęły skandować: Mao zhuxi wansui, Mao zhuxi wansui - „Niech żyje Przewodniczący Mao”, „Niech żyje Przewodniczący Mao!” Dosłownie znaczyło to „dziesięć tysięcy lat dla Przewodniczącego Mao", co było tradycyjnym życzeniem dla cesarza. Na koniec zaś: wanwansui „dziesięć tysięcy razy dziesięć tysięcy”.

Zanim jednak doszliśmy do tego apogeum życzenia „stu milionów lat życia”, już po kwadransie rytmicznych okrzyków tych dzieci i całego tłumu na placu nie- 
mal całkiem ogłuchłem. Tłum bowiem krzyczał z entuzjazmem i przejęciem, ile sił, z chińską gorliwością. Patrzyłem coraz bardziej niecierpliwie na zegarek, bo czułem się jak nieszczęsny gołąb wsadzony do czaszy bijącego dzwonu, a te krzyki trwały i trwały, rozsadzając głowę całą, a nie tylko bębenki. Niektórzy z cudzoziemców zasłonili uszy dłońmi i zamknęli oczy. To było bowiem wręcz nie do zniesienia! A nie chodziło przecież tylko o sam hałas, lecz i obcy nam entuzjazm polityczny i o ten thum $\mathrm{w}$ dole, napierający na pomalowane na purpurowo ceglane bryły trybun. Wydawało się wręcz, że to całe Chiny tak oddane są Mao i szaleją z radości. Trudnym doświadczeniem była dla nas, cudzoziemców, już ta niewyobrażalna masa ludzi, a co dopiero krzyczących z tak fanatycznym oddaniem!

Umęczeni ogromnie wróciliśmy autobusami na uczelnię. Wieczorem zaś znowu pojechaliśmy na Plac oglądać rozmaite występy, wprost na jego płycie, w różnych miejscach. A potem nastąpił półgodzinny, niewiarygodnie piękny pokaz ogni sztucznych, wynalezionych przecież w Chinach. W Polsce nigdy wcześniej nie widziałem czegoś podobnego. Byłem zupełnie pijany barwami, głośną muzyką chińską, śpiewami, a nade wszystko tymi rozradowanymi thumami. Przez całe swoje życie nie widziałem tylu ludzi, ilu tego jednego dnia. Trzeba pożyć trochę w tym kraju żeby zrozumieć częste Chińczyków utyskiwania: „ludzi u nas za dużo!” Nie tylko w Chinach, ale w całej Azji Wschodniej człowieka Zachodu poraża tłum i ustawiczne życie w ciżbie.

Następnego roku na święto narodowe zamiast na Plac Tiananmen poszedłem na włóczęgę po mieście. Jak się okazało, ulice gdzie gromadzili się i maszerowali manifestanci, zostały szczelnie odgrodzone od reszty miasta szeregami policjantów i żołnierzy. Do uprzywilejowanej strefynie dopuszczali nikogo z postronnych. Zwykły Chińczyk nie miał zatem szans nawet zobaczyć tej parady, co dopiero wziąć w niej udział. Uroczystość była tylko dla wybranych! Dla zwykłych ludzi był to po prostu świąteczny dzień, wolny od pracy zarobkowej. W pekińskich zaułkach - hutongach - toczyło się normalne życie. Kobiety prały, albo szykowały obiad na stojących w podwóreczku piecykach. Mężczyźni coś majstrowali, albo robili koło domu, niektórzy bawili się z dziećmi. Uliczni sprzedawcy zachwalali swój towar. Cały ideologiczny zgiełk Placu Tiananmen tu nie docierał i nikogo nawet nie obchodził.

Przypomniał mi się wtedy incydent z epoki Tang, kiedy to barbarzyński książę z Południa przyjechał złożyć hołd do stolicy. Zanim pozwolono mu odwiedzić największy targ, poinstruowano tamtejszych kupców, że mają szanownemu gościowi wręczać wszystko, czego sobie zażyczy odmawiając przyjmowania zapłaty. Mieli mu mówić: „nasz kraj tak jest bogaty, iż jest dla nas szczęściem wręczać ten drobiazg jako upominek Jego Wysokości”. Oczywiście zapłacić miało za to potem Mi- 
nisterstwo Norm (czy Etykiety - Li bu - zawiadujące przyjmowaniem poselstw). Miało to sens jedynie w systemie zamknięcia kraju dla cudzoziemców, izolowania go i tworzenia o nim złudnych wyobrażeń. Podróż Chińczyka zagranicę wymagała przez tysiąclecia zezwolenia władz najwyższych, więc nie zdarzało się to często. Dlatego to kupcy arabscy i bliskowschodni zajmowali się handlem z Cesarstwem, gdyż kupców chińskich na ogół nie wypuszczano. Cudzoziemców zresztą też dopuszczano niechętnie do wysoko rozwiniętych Chin, podobnie jak dzisiaj zamykają się przed biednymi świata bogate kraje Zachodu. Gdy w końcu XVIII w. lord Macartney przyjechał ze sławnym listem króla Anglii do cesarza, z Kantonu do Pekinu wieziono go dżonkami, w których widok na kraj zasłaniały mu parawany, albo też niesiono go zamkniętymi lektykami. Tak poseł przejechał cale Chiny oglądając tylko niebo oraz wnętrza otoczonych murem rezydencji, w których go goszczono, gdzie go z lektyk wypuszczano i do lektyk ładowano.

Na początku lat sześćdziesiątych ludność Pekinu była poinstruowana, by wszelkich kontaktów z cudzoziemcami unikać, a jeśli taki czegoś chce - doprowadzać go do policjanta, który już zaopiekuje się nim odpowiedzialnie. Na jednym z zebrań wspólnoty uliczkowej instruowano ludność, jak postępować z cudzoziemcem pytającym o ulicę. Podobno padło wtedy pytanie: a jeśli cudzoziemiec jest Albańczykiem? Przypomnieć zaś trzeba, że Albania była wtedy najbliższym sojusznikiem Chin, „,dzielącym rewolucyjne bohaterstwo oraz wierność marksizmowi-leninizmowi". Odpowiedź padła następująca: należy najpierw zapytać cudzoziemca z jakiego jest kraju, a potem odprowadzić go do policjanta. Izolacja Chin za czasów Mao oraz ścisłe oddzielanie cudzoziemców od Chińczyków wyrastały $\mathrm{z}$ tradycji utrzymywanej od ponad dwu tysiącleci. Zresztą trudno byłoby narzekać na brak postępu: podczas gdy prawa antycudzoziemskie z XVIII w. przewidywały ścięcie głowy za próbę uczenia cudzoziemca języka chińskiego, nas przecież wręcz uczono go na koszt państwa!

Mimo antycudzoziemskich restrykcji epoki Mao zdarzało się, choć rzadko, że ktoś korzystał z okazji i starał się porozmawiać z cudzoziemcem. Dość bezpiecznym dla Chińczyka pretekstem było pomaganie "zabłąkanemu", czy doprowadzanie go gdzieś. Tak poznałem wielu ludzi, od rodziny chłopskiej z przedmieścia, którą później często odwiedzałem, aż po profesora filozofii, który sam zagadnął mnie obok bramy Uniwersytetu Pekińskiego. Samoizolacja Chin nie była zatem tak całkowita, jakby to z partyjnych instrukcji wynikało. Poznawałem zatem Chiny przy znacznej pomocy Chińczyków, od których też dowiadywałem się o dziesiątkach spraw, o jakich cudzoziemiec wiedzieć nie powinien. Nawet rzeczy tak bulwersujących, że nadal w mieście funkcjonują nielegalne burdele. Jeden, który mi pokazano, mieścił się obok pryncypialnej ulicy Wangfujing nad warsztatem zegarmistrzowskim. Zatem przychodzący tam obcy mężczyźni nie zwracali szczególnej uwagi, na dole był przecież prawdziwy zegarmistrz! Nie należy sobie zatem 
wyobrażać, że w epoce Mao komunistyczne wzorce były naprawdę realizowane w pełni i powszechnie.

Mao wcielił wprawdzie na nowo w życie konfucjańskie jeszcze ideały „,społeczeństwa doskonałego moralnie”, wychowywanego przez państwo - gigantyczną szkołę, z cesarzem i jego mandarynami jako nauczycielami, lecz był to swoisty teatr, w którym wszyscy byli aktorami i widzami jednocześnie. A Mao, jak dawni Synowie Nieba, nauczał lud tego, co dobre i złe. Jak w cesarstwie manifestowano wierność cnotom konfucjańskim i wygłaszano napuszone, słuszne moralnie, tyrady, tak w epoce Mao okazywano wierność głoszonej przezeń rewolucyjnej moralności oddania ludowi i poświęcenia, by uszczęśliwić całą ludzkość.

Anioły komunistycznie przemienionych nowych ludzi nie musiały nawet unosić się rzeczywiście nad ziemią. Wystarczało, by na zawołanie machały przyczepionymi do ramion tekturowymi skrzydłami i trochę podskakiwały. Najmniej gorliwe zmuszane były do podskoków przez uwagi kolegów i baciki wychowawców, śmigające po nóżkach. Nie trzeba jednak było uciekać się do tego nazbyt często: aniołki były wyćwiczone do podskoków od ponad dwu tysięcy lat, tylko pompatyczne deklaracje słowne zmieniały się, w XX w. aż kilkakroć. Nie był to jednak tylko teatr. Jeśli społeczność gra jakąś sztukę przez ponad dwa tysiące lat, aktorzy zrastają się ze swoją rolą i bez niej nie wyobrażają sobie życia, a mówią i myślą przypisanymi im rolami. Tak wpojony został konfucjanizm, a później podobnie zrytualizowany maoizm, z takim samym rygoryzmem moralnym, jedynie uzasadnianym inaczej.

Pewnego razu wyjeżdżając w niedzielę do miasta zobaczyłem dwu żołnierzy wychodzących z pobliskich koszar. Pomyślałem, że warto zmienić plany i zobaczyć, z jakich rozrywek korzystają wojownicy Przewodniczącego Mao. Zsiadłem więc $\mathrm{z}$ roweru i cały dzień włóczyłem się za nimi. Byłem ubrany po chińsku, więc nie zwracałem na siebie zbytnio uwagi. Najpierw wybrali się do Muzeum Historii, potem do Parku Północnego Morza, gdzie pili lemoniadę, coś przekąsili, pływali łódką przekomarzając się wesoło z pasażerami innych łódek. Tak kulturalnie spędzili wolny dzień... I wrócili do koszar.

Koszarowy komunizm Mao łączył konfucjański rygoryzm moralny z feudalnymi stosunkami. Przypomnijmy może, iż w tych czasach zbliżenie studenta ze studentką, mieszkających zresztą w tych samych domach studenckich, pokój w pokój, mogło stać się na wiele miesięcy przedmiotem roztrząsań i samokrytyk na zebraniach organizacji młodzieżowej. A obwinieni musieli szczegółowo opowiadać, gdzie w tym momencie on położył rękę, a co zrobiła ona. Do ślubu, specjalnie odkładanego, dziewczyna musiała zachowywać dziewictwo i myśleć o rewolucji, a nie o zberezeństwach!

Ludność dzieliła się wtedy na „lud” (renmin) i „kadrę” (ganbu). „Kadrowcy” kierowali ludem, gdziekolwiek by się nie znajdowali, i pouczali go. Wyróżniali się nawet strojem: mieli bluzy z czterema kieszeniami, a nie z trzema, jak zwykły 
Chińczyk ,z ludu”, a górne kieszenie przykryte były patkami. W lewej była zaś wycięta specjalna dziurka na wystające wieczne pióro do pisania, bo „kadrowiec” powinien być piśmienny. „Kadrowcami” byli wszyscy zarządzający, a ich pozycję i przywileje określały rangi, równie precyzyjnie jak w wojsku, co było starą tradycją biurokracji chińskiej. One określały ilumetrowe mieszkanie mu przysługuje, ile służby, a do podróży rower, samochód, czy samolot specjalny. Gdy wchodziłem do autobusu miejskiego, taki kadrowiec spędzał z miejsca najbliższą osobę, choćby to była siedemdziesięcioletnia staruszka, by okazać uprzejmość ,,cudzoziemskiemu przyjacielowi” (waiguo pengyou). Gdy raz uparłem się i nie chciałem zająć miejsca staruszki, cały autobus mnie przekonywać zaczął, bym usłuchał kadrowca i przyjął grzeczność ludu, włącznie z kierowcą. Ustąpiłem, gdy się stało jasne, że inaczej nigdy nie pojedziemy... Pewnego razu latem szedłem ulicą Wangfujing. Widzę zbiegowisko, w środku kobieta leży na trotuarze. Przystanąłem i pytam najbliższego Chińczyka, czy wezwali pomoc. „Czekamy na przechodzącego kadrowca, by wezwał pogotowie”. Koledzy chińscy objaśnili mi potem, że to przecież oczywiste, iż mógł to zrobić jedynie kadrowiec. ,Jak sobie wyobrażasz? Przecież mnie kierownik sklepu nie pozwoliłby skorzystać nawet z telefonu! A gdybym do pogotowia zadzwonił, to co bym powiedział? Ja, towarzysz Zhang, wzywam lekarza? Zupełnie co innego, gdy mówi kadrowiec taki to i taki, z takiej to instytucji, określonej rangi..."

Co najbardziej mnie w Chinach zaskoczyło? Chyba trzy rzeczy: brak poczucia ,prywatności”, brak indywidualistycznej osobowości, o jakiej uczyłem się na studiach jako właściwej każdemu człowiekowi, i względność norm kulturowych, które wcześniej wydawały mi się ,regułami naturalnymi”. Prywatność? A kiedyż Chińczyk jest sam? Wieś od wsi odległa o pół kilometra. Czy nawet mniej. Jeśli by chłopak zechciał pójść „,w krzaki” z dziewczyną, będą ich oglądać sąsiedzi przynajmniej ze trzech wsi naraz! Kiedyś wieczorem byłem w parku w Szanghaju. Szliśmy ostrożnie środkiem ścieżki świecąc latarką pod stopy i starając się nie nadepnąć na wystające na dróżkę nogi. Wydawało się, że każdy krzaczek ,jest zajęty" i to nawet z kilku stron naraz. W każdej izbie mieszka po kilka, nawet i dziesięć osób. Ludzie tu są ustawicznie razem. Publiczne ubikacje, nawet „eleganckie”, wykładane terakotą, to długie ławy cementowe z nieskończoną liczbą „oczek”, bez jakichkolwiek ścianek działowych, nie mówiąc o drzwiczkach. Z okien pekińskich autobusów, czy trolejbusów, można było oglądać przy domostwach „,fizjologiczne ogródki" od ulicy oddzielone murkiem prawie wysokości człowieka, lecz widzowi z okna autobusu ukazywały one całe swoje wnętrze z ewentualnymi ,gośćmi" we wszelkich fazach załatwiania się. Europejczykowi z trudem przychodziło się uczyć, że wszelkie „wydalanie organiczne” jest czynnością naturalną i nie ma 
w sobie nic wstydliwego. Ba, jego próba pójścia w celu fizjologicznym w pole mogła wręcz zgromadzić całą wieś, traktującą to jako interesujące widowisko. Jak też taki ,,czort zamorski” to robi?

Podobnie nie łatwo było mi się uczyć, że właśnie czynność jedzenia ma charakter ,intymny”. Wszyscy „lepsi goście” w restauracji idą na piętra, do pokoiczków na jeden stół, gdzie można w gronie przyjaciół, lub rodziny, rozkoszować się jadłem dowoli. Pluć, mlaskać, oblizywać, rzucać kości na stół i na podłogę, beknąć, czy nawet od biedy i pierdnąć sobie wygodnie. Zjedzenie symboliczne razem i wypicie czarki wina przez chłopca i dziewczynę, koniecznie przy świadkach, zawiązywało małżeństwo. Rola, charakter i ogromne znaczenie jedzenia w kulturze chińskiej to zresztą temat odrębny.

My, ludzie Zachodu, poszukujemy towarzystwa. Picie piwa, wina, czy wódki służy nam głównie do stwarzania szczególnego „braterstwa bycia razem”. Dotyczy to także i Japończyków, którzy na trzeźwo mają kłopoty z „byciem razem”. Chińczycy zaś stale będąc razem, poszukują izolacji, choćby iluzorycznej, jak stanie z wędką w odległości aż trzydziestu metrów od sąsiedniego wędkarza, czy jak uprawianie wraz z innymi ćwiczeń gimnastyczno-oddechowych qigong z pogrążaniem się w sobie, albo jak dawniej i znowu ostatnio - z fajeczką opium. Zwróćmy uwagę, iż dla „,chwili samotności” Chińczyk poszukiwał towarzystwa innych: będąc obok siebie zapadali w swoją samotność. W Chinach stale jesteśmy bowiem z innymi. Oni nas obserwują, pouczają, krytykują, ale i wspierają. Bycie samemu, tak dosłownie, bez innych ludzi wokoło, jest doświadczeniem nader rzadkim, czasem - choćby na trochę - pożądanym, choć zwykle sprawia dotkliwą przykrość, bywa wręcz nie do zniesienia i staje się surową karą. W tradycyjnym wychowaniu płaczące dziecko wystawiano na podwórko nawet w nocy. Szybko uczyło się więc, że wrzaski i lamenty nie wywołują zbiegania się całej rodziny, zajmowania szkrabem, przytulania i huśtania na rękach, a wręcz odwrotnie powodują oddzielenie w samotność i wystawienie w ciemność. Dlatego jeszcze w latach sześćdziesiątych dzieci chińskie nie płakały. Życie w tłumie było szczególną sztuką rozwiniętą w Azji Wschodniej i sposobem życia tam.

Adam i Ewa jako prarodzice tworzą u nas pierwszą parę i dalej płodzą dzieci, niektóre - jak Kain i Abel - znane nam nawet z imienia. Chińska Nü Wa lepi figurki z gliny, one natychmiast ożywają i odbiegają. Zmęczona tym, zanurza sznurek w rozrobionej glinie i wypręża go, wtedy odrobiny błota odrywają się i padają na ziemię zamieniając się w ludzików. Zanurza i wypręża, i znowu, i znowu... Ludzi więc od początku były tysiące. „Człowiek” to w tej wizji zbiorowość, nie zaś jednostka, jak mniemamy na Zachodzie. A to różnica fundamentalna. 
Wspomniane powyżej hutongi, owe malownicze zaułki dawnego, parterowego i na wpół wiejskiego Pekinu, też poznawałem „w sposób praktyczny”, nawet tam nocując. Byłem wtedy chyba jedynym cudzoziemcem w Pekinie łamiącym tyle zakazów na raz. Gdy teraz oglądam nostalgiczne albumy ukazujące ich piękno w starych fotografiach, piękne detale kamieniarskie, czy cyzelowane rzeźby w drewnie, ja wiem, jakie tam były warunki życia. Jedna izba na rodzinę, w klitkach wciśniętych jedna obok drugiej, ze wspólnym podwóreczkiem na kilkanaście metrów kwadratowych dla kilkudziesięciu osób. Z jakimiś roślinkami w doniczkach, czy nawet w starych puszkach. Śmierdziało tam niemożebnie. Krany z wodą były tylko na rogach skrzyżowań, a chodziło się do toalet publicznych z dołami kloacznymi, po jednej na kilka zaułków. Mnie odbierało dech, gdy musiałem z nich korzystać. Nieczystości wylewało się na uliczkę...

W centrum stolicy było wtedy ledwo kilka budynków wielopiętrowych: Hotel Pekin koło Wangfujingu, Muzeum Narodowości z hotelem obok, gmach radia... A i to mówimy o budynkach siedmio, ośmio, czy dziesięciopiętrowych. Całe niemal miasto było parterowe, przy uliczkach handlowych często domy bywały jednopiętrowe, ze sklepem, czy warsztatem na dole i mieszkaniem na górze. Dom towarowy był jeden, właśnie przy ulicy Wangfujing. Dziś jest ich pewnie kilkadziesiąt, $\mathrm{i}$ to takich, jakich nie znajdziemy w Warszawie. A owo stare - w dosłownym sensie - miasto znikło pod nowoczesną, monumentalną zabudową. Pod nowoczesnymi arteriami, chyba już z pięcioma obwodnicami utrzymującymi jako taką przejezdność miasta przy eksplozji prywatnej motoryzacji. Chyba najbardziej razi ta zmiana w przypadku lamaistycznej świątyni Yinghegong. Dawniej wznosiła się ona imponująco nad otaczającymi zaułkami, a w latach dziewięćdziesiątych znalazła się tuż obok estakad autostrady biegnących na wysokości jej dachów i wśród wysokościowców, wśród których niknie niemal całkowicie.

Wtedy panowała jakaś niezrozumiała „fobia trawy”: wszędzie ją wyskubywano, by ziemia była „porządna”, goła, ubita... Nawet w parkach widać było całe klasy dzieci szkolnych pracowicie wyskubujących roślinki wybijające się z ziemi. Przy ulicach rosły wprawdzie drzewa, ale nieliczne trawniki i kwietniki znaleźć można było jedynie w parkach. Gdy zawiał więc wiatr, wzbijały się od razu masy żółtawego pyłu. A wiatry w Pekinie wieją niemal nieustannie, najmniej jesienią. Teraz cały Pekin jest zielony i pełen kwiatów. Dodajmy, że nie tylko nowe jest niemal całe miasto, ale i inni są jego mieszkańcy, jakbyśmy przyjechali do zupełnie innego kraju.

Jak żyło się w Chinach za czasów Mao, na początku lat sześćdziesiątych? Po nieudanych eksperymentach Wielkiego Skoku, kilku latach chaosu gospodarczego i niedojadania, a niekiedy wręcz i głodu, ,polityka uregulowania” wprowadzo- 
na przez Deng Xiaopinga i Zhou Enlaia (Czou En-laja) zaczęła przynosić owoce i kraj zaczął żyć „w skromnym dostatku”. Oczywiście był to dostatek względny, kraju biednego i zacofanego gospodarczo. Pamiętajmy, że około 1950 r., kiedy to tak Chiny jak i Indie zaczynały byt niepodległy, w tej byłej kolonii brytyjskiej PKB na głowę mieszkańca był niemal dwukrotnie wyższy niż w Chinach! To dopiero dziś Chiny wyraźnie wyprzedziły Indie pod względem warunków życia i u końca XX w. ich PKB na głowę był o jedną trzecią wyższy niż tam i osiągnął prawie połowę wysokości PKB w Polsce na głowę. Dodajmy, że wzrost rozmaitych wskaźników jakości życia rósł w Chinach w latach 90. najszybciej w świecie!

W Chinach z lat sześćdziesiątych ludzie chodzili zazwyczaj w połatanych, bawełnianych ubraniach. Czasami była to łata na łacie, tak że z pierwotnego materiału nawet nie zostało śladu. Ale wszystko było czyste, wyprane. Moi koledzy studenci mający po dwie pary spodni na lato, dwie koszule, i watowane ubranie na zimę - byli „znakomicie zaopatrzeni”. A pamiętajmy, że w Pekinie upały zaczynają się w końcu kwietnia i trwają do września. Człowiek więc poci się nieustannie, brudzi, i wszystko trzeba stale prać. Tkaniny były dostępne tylko na kartki i to z bardzo skromnymi przydziałami. Opowiadano mi, że nieliczne wówczas pekińskie prostytutki od cudzoziemców zazwyczaj żądały właśnie kuponów płóciennych, cenniejszych od pieniędzy. Wszyscy wówczas wdziewali granatowe, mniej czy bardziej wyblakłe od prania, „mundurki Mao”, w istocie wprowadzone jeszcze przez Sun Yat-sena u początków XX stulecia. Jeden z kolegów-indywidualistów na Uniwersytecie Pekińskim nabył sobie zielony, co bardzo zbulwersowało miejscowych aktywistów młodzieżowych, ale wybronił się, że to kolor wojskowy, a wojsko jest przecież wyjątkowo rewolucyjne i wierne Mao. Kobiety od stuleci nosiły w Chinach spodnie i tylko elegantki latem wkładały jakieś luźne plisowane spódnice typu zachodniego do białej, czy kremowej prostej bluzki. Spódnica bywała jednak odzieniem ryzykownym przy częstych i silnych wiatrach. Pamiętam jak szliśmy z kolegami z Birmy centralną Aleją Chang'an za elegantką zgiętą we dwoje i trzymającą przód spódnicy przy kolanach. Nie wiedziała jednak biedaczka, że tył jej sukienki leżał na plecach, ukazując dosyć zgrzebne majtadały. Żadnych rzeczy kolorowych. Obowiązywała skromność rewolucyjna i używanie wszystkiego aż do zdarcia. Oczywiście nie było żadnych mód, potępiano nawet użycie szminki. Ulice były więc granatowo-białe. Jedynie wspomniani kadrowcy - stanowiący „elitę kierującą” wyróżniali się nieco lepszym przyodziewkiem. U wyższych szarż nawet wełnianym, a u najwyższych rang szarym i barwy kawy z mlekiem, ale tak wysokich dostojników na ulicy się nie spotykało, oczywiście.

Na kartki był ryż i wszystkie produkty mączne, jak też olej niezbędny do smażenia. Mięso od tysiącleci uchodziło za produkt luksusowy, było więc dostępne, choć stać na nie było jedynie zamożniejszych. Od starożytności podstawową rolę w wyżywieniu odgrywają w Chinach warzywa i produkty sojowe, zastępujące białko zwierzęce. Tak pierwszych, jak i drugich była obfitość, w sklepach i na rynecz- 
kach, po dostępnych cenach. Pół kilo (jin) pomidorów kosztowało pięć fenów, kilka fenów - główka bardzo tam popularnej kapusty pekińskiej. Jabłka i dość marne chińskie pomarańcze kosztowały po 1.40 (chyba yuanów?) kilo. Przeciętna pensja wynosiła wtedy 40-60 yuanów, tylko szefowie wyższych rang zarabiali ponad sto yuanów. Moi chińscy koledzy-studenci ryż widywali tylko od święta, z kawałeczkami mięsa czy drobiu; na co dzień zadawalać się musieli ciemnymi kluskami, albo też dość ciemnymi bułami gotowanymi na parze i jakimiś smażonymi warzywami, czy zupą z zieleniną.

Niedaleko mojej szkoły był sklep, zazwyczaj pustawy, który mnie poraził asortymentem: sprzedawano w nim, prawda, że przy odrębnych ladach - węgiel i drewno na podpałkę, mięso oraz ryby i wódkę. Było to logiczne: jeśli już ktoś robi bankiet, to mięso będzie chciał na czymś lepszym ugotować, niż zwyczajny miał lepiony pracowicie $\mathrm{w}$ gomółki, i pewnie też zechce podać coś do popicia na początek. Wspomnijmy, że pijaństwo było tam nieznane. W ciągu dwu lat chyba ze dwa razy widziałem wyraźnie podchmielonego mężczyznę.

Dla przybysza z Polski epoki Gomułki porażające były dwa zjawiska: brak kolejek w sklepach i ich niezmiernie obfite zaopatrzenie, przy tym w produkty rozmaitej klasy. W Warszawie można wtedy było kupić, na przykład, tylko dwa rodzaje pasty do zębów: zwykłą miętową i dla dzieci, o smaku owocowym. Wszystko było obliczone na „średnią kieszeń”. W Chinach natomiast, mimo ideologii radykalnego egalitaryzmu, oferowano produkty bardzo zróżnicowane. W Pekinie, w specjalnym stoisku z pastami do zębów w głównym domu towarowym przy Wanfujingu, było ich ponad siedemdziesiąt! Od najtańszego proszku do czyszczenia zębów, pięć fenów za pudełko, aż po super elegancką, eksportową do Hongkongu, pastę za ponad pięć yuanów.

Kiedyś zamierzałem wysłać paczuszkę do rodziny i chciałem nabyć arkusz papieru pakowego. W Warszawie byłby go jeden rodzaj, i to niekoniecznie. W Pekinie na pytanie o papier, sprzedawca podał mi całą książeczkę z najróżniejszych kartek do wyboru. Osłupiałem wtedy, gdyż nawet sobie nie wyobrażałem, że papieru może być aż tyle rodzajów! Kolejki pojawiały się tylko sporadycznie i to po produkty szczególne: na przykład po dzieła Mao, kiedy się pokazały, czy produkty rzadkie. Kiedyś zaintrygowany kolejką aż dziesięcioosobową nabyłem, na przykład, wędzone maciczki młodych świnek.

Nie było ani prywatnych telefonów, ani prywatnych samochodów. Najdroższym sprzętem technicznym, jaki rodzina mogła posiadać, był rower. Wentylator i zegarek - były „znamionami zamożności”. Najczęściej używane żarówki miały moc 20 wat, czterdziestki biły więc jasnością. Choć latarnie uliczne zazwyczaj dawały podobnie marne światło - wieczorem mężczyźni pod nimi siadywali coś czytając. Było tam jednak jaśniej niż w domu. Standardy życia były zatem o wiele niższe niż w Polsce i oczywiste było techniczne zacofanie kraju. Wspomnijmy, że długość linii kolejowych w Polsce i w Chinach była wtedy zbliżona, mimo 
ogromu tego azjatyckiego kraju. Nie tworzyły one sieci, jak u nas, ale były liniami prowadzącymi skądś dokądś, jak u nas w czasach kolei warszawsko-wiedenskiej. Zaopatrzenie dla mieszkańców miast było wszakże niepomiernie lepsze niż w Polsce. Sklepy chińskie i stragany na rynkach imponowały obfitością wszelkich dóbr, niewyobrażalną w Warszawie. Lepsza była też jakość wszelakich produktów i obsługa.

Oto dwa wymowne przykłady. Do sklepu z artykułami żywnościowymi (celowo nie używam terminu „spożywczego") przychodzi starsza kobieta i chce nabyć jajka. Sprzedawczyni skonfundowana mówi, że chwilowo zabrakło. Baba się sierdzi. Wzywa kierownika i ruga personel sloganami maoistowskiej propagandy, że „nie umie on służyć ludowi”. Kierownik pokornie jej tłumaczy, że zaraz jajka będą, ktoś się po prostu zagapił i nie zamówił dostawy. Proponuje, by za godzinę przysłała może wnuczka, a zapłacić za nie może od razu. Baba wychodzi pomstując. Osoby znające sklepy epoki komunistycznej w Polsce, z opryskliwymi i nieużytymi „księżniczkami za ladą”, zrozumieją moje osłupienie w takiej sytuacji.

Scenka druga. Późnym wieczorem wracam rowerem z ambasady na drugim krańcu stolicy. Około dziesiątej miasto jest już wymarłe. Ciemno. Przy ulicy na rozłożonych matach, albo wyniesionych $\mathrm{z}$ domu prymitywnych łóżkach, w poszukiwaniu choć odrobiny ochłody, śpią ludzie. Z mojego roweru uszło powietrze, pewnie przedziurawiła się dętka. Jechać dalej nie sposób. Znajduję portiernię jakiegoś zakładu i proszę dyżurnego, żeby mi przez telefon wezwał taksówkę, podaję mu numer. A rower zostawię do jutra. W dzień sobie jakoś poradzę. Strażnik mi thumaczy, że zaraz za rogiem jest warsztat naprawy rowerów, to mi przecież zreperują. Na moje obiekcje, że przecież już późno tłumaczy, że jego "gospodarz" (zhuren), zapewne dawny właściciel teraz „uspółdzielczony”, śpi w warsztacie, tylko go trzeba dobudzić. Przełamując moje onieśmielenie w końcu idzie tam ze mną i wali ręką w nędzną budkę. Wychodzi zaspany rzemieślnik w samych majtkach. Bierze się do roweru. Nie jest nazbyt rozmowny, rzecz jasna. Stwierdza, że tylko obluzował się wentyl. Wszystko dokręca i pompuje koło. „Ile płacę?”. „Nic” - odburkuje bez zbytniej uprzejmości - „niczego nie wstawiłem, nie wymieniłem, to nie należy się". Wiedziałem, że napiwku dawać nie wolno. Mogłem więc tylko podziękować i odjechać. Dziś to nie do wyobrażenia. Ideologia "służenia ludowi” dawno została zarzucona, teraz każdy tylko zabiega o pieniądze...

Chiny epoki Mao miały więc rozmaite oblicza i nie dziwię się nawet, że żywe są nostalgiczne tęsknoty za nimi. Choć dzisiejszych warunków życia nie sposób porównać do ówczesnych. A i o feudalnych podziałach na stany oraz o tradycyjnej obyczajowości też dawno zapomniano. 
Pamiętam też dobrze ostatni dzień przed moim odjazdem do Polski. Był sierpień 1966 r. W maju rozpoczęła się właśnie Rewolucja Kulturalna. Miałem nadzieję, że wyjeżdżam tylko na rok, a powrócę gdy tylko sytuacja nieco się uspokoi. Byłem świadkiem narastania kryzysu politycznego, z którego wymiaru nie zdawałem sobie jednak sprawy. Dopiero po wydarzeniach jesteśmy w stanie je ocenić i zrozumieć sens rozmaitych drobiazgów. Zimą burzyć zaczęto mury stolicy, której bramy wciąż można było zamknąć, jak w średniowieczu, nie dopuszczając ludzi z zewnątrz. Z kolei ogrodzenia uczelni zaczęto reperować. Bez tego nie mogłyby się stać one później zamkniętymi centrami „ruchu rewolucyjnego”. Wszyscy moi koledzy z Uniwersytetu Pekińskiego, gdzie jesienią zacząłem chodzić na wykłady z historii, etnografii i języka klasycznego, zostali wysłani na wieś „dla hartowania rewolucyjnego ducha w pracy fizycznej”. A niektórzy z nich byli rozdyskutowani politycznie. Pamiętam jak pewnego razu, gdy krytykowałem wysiłki aktywistów narzucania wszystkim studiowania myśli Przewodniczącego, jeden z nich cwanie się uśmiechając powiedział: „Gdybyśmy mogli, nawet Przewodniczącego Mao zasadzilibyśmy do postudiowania jego tekstów z okresu walk rewolucyjnych". Zrobiło to wtedy na mnie wielkie wrażenie i zrozumiałem, że nie chodzi im wcale o gloryfikowanie osoby Mao, lecz ze studiów jego dzieł czynią ruch w istocie rewolucyjny i antyrządowy. Uznają, że rewolucja komunistyczna zapomniała o swoich dawnych ideałach i rządy sprawuje „nowa burżuazja”. Kluczową kwestią stały się przywileje biurokracji partyjno-państwowej. Narastające nierówności było widać nawet na ulicy. W soboty i niedziele aleją prowadzącą w kierunku Wzgórz Pachnących śmigały czarne limuzyny dostojników wyładowane tłustymi babami, dzieciakami, bambetlami. A obok jezdnię wypełniał tłum rowerów i riksz towarowych, czasem prowadzonych nawet przez staruszków z największym trudem naciskających pedały rikszy wyładowanej aż bezsensownie. W tej powszechnej biedzie luksus raził szczególnie. Brat jednego z moich kolegów z miasta, uczeń liceum, opowiadał mi w maju 1996 r. jak to w ich szkole uczniowie kijami zatłukli nauczycielkę wychowania politycznego. „Nas uczyła rewolucyjnej skromności, a sama w tajemnicy jadła mięso!” Dla wiecznie półgłodnych chłopców, jedzących tylko zieleninę z sosem sojowym, to było ,przestępstwem politycznym” i przejawem ,degeneracji ideologicznej”. Emocje też inaczej grają przy pustym brzuchu. Bolały i bulwersowały nie tyle same nierówności, co zakłamanie: zalecanie rewolucyjnych cnót i wyrzeczeń przez beneficjentów systemu, podczas gdy sami oni „pławili się w luksusie”.

Pamiętam wiece rozhisteryzowanej młodzieży, ze łzami lejącymi się po twarzach dziewczyn ... i mokrymi kałużami, które pozostawały potem na ziemi. Zupełny amok. Ale porywali się oni niemal na świętokradztwo: na „,bunt przeciw władzy" - w Chinach rzecz niesłychaną, przeciwko starszym i przeciwko rządzącym weteranom rewolucji. Kto tym ruchem i jak sterował - nie było wtedy jasne. Na uczelniach i w dzielnicach zaczynało się wywieszanie , gazetek wielkich hierogli- 
fów" z najrozmaitszymi pretensjami wobec władz i poszczególnych funkcjonariuszy. Wyciągano dawne krzywdy realne i urojone, ,przestępstwa przeciwko ludowi”, wszystkie bóle dotychczas skrywane. Pamiętam jak stare kobiety parasolami dziobały postawionego na krzesełku sekretarza partii dzielnicy Haidian: „Na kim się tak upasłeś? Na nas!” A partyjny dygnitarz trzęsąc się ze strachu przepraszał zbuntowany lud za swe przewiny. Ale także wypowiadano publicznie rozmaite poglądy, kłócono się, jak należałoby „budować socjalizm”.

Ruch ten inspirował i wykorzystał Mao, by odzyskać władzę, ale napięcia polityczne i społeczne były realne, podobne jak w innych „krajach socjalistycznych”. W Polsce zaowocowały one wypadkami poznańskimi, czy w Trójmieście, ale u nas na czele protestu nie stanął legendarny przywódca rewolucji komunistycznej, jak w Chinach, który postanowił zgnieść partię, jaka go zdradziła. Sekretarz partii w naszej szkole, były uczeń Mao z Yen'anu, powiedział mi jeszcze w lutym w zaufaniu, że w kierownictwie trwa wielka dyskusja o dalszej polityce Chin, także wobec Związku Sowieckiego. Oczekiwał zmian politycznych i pewnej liberalizacji. Nie przeczuwał, że studenci i jego wywleką, gdy kontrowersje te rozgrywane będą na ulicach. Niezadługo zresztą i aktywistów Czerwonej Gwardii, oskarżonych o najróżniejsze przewiny, zesłano na reedukację na wieś, do warunków morderczych dla mieszkańców miast. Armia kładła kres radykalnemu, komunistycznemu ruchowi, który pogrążył kraj w chaosie... Ale wtedy byłem już w Polsce. Wyjechałem niedługo po pierwszych spotkaniach Przewodniczącego Mao z czerwonogwardzistami na Placu Tiananmen.

Nie zapomnę do końca życia pewnej nocy. W Instytucie Języków Obcych, po drugiej stronie drogi, gdzie odbywały się wszystkie wiece, gdyż u nas byli cudzoziemcy, trwał taki wiec „rewolucyjnej krytyki i samokrytyki”. Przez głośniki słychać było krzykliwe oskarżenia, a potem wycie męczonego, i znowu oskarżenia, i wycie... Nigdy nie przypuszczałem, iż człowiek może wydawać z siebie odgłosy tak nieludzkie. Siedzieliśmy z moim kolegą, Nepalczykiem, rozdygotani i przerażeni, zgasiliśmy nawet światło. Spać było nie sposób. A wiec ciągnął się godzinami. Następnego dnia rano obok bramy sąsiedniej uczelni na piachu drogi widziałem ślady krwi...

Przedstawianie dzisiejszych Chin jako straszliwej dyktatury komunistycznej, tak jakby wciąż tam trwała Rewolucja Kulturalna jest tylko świadectwem monstrualnej ignorancji i zacietrzewienia politycznego. Rewolucja Kulturalna trwała w istocie tylko od wiosny $1966 \mathrm{r}$ do wiosny $1969 \mathrm{r}$., kiedy to IX zjazd odbudowywanej KPCh przywrócił pewną stabilność polityczną pod patronatem wojska. A od tego czasu ileż się w Chinach wydarzyło... Chiny są dzisiaj krajem post-komunistycznym, podobnie jak Polska, czy Rosja, choć odejście od komunizmu inaczej się tam dokonało. Osadzenie ostatnich hierarchów komunistycznych w więzieniach, tak zwanej „bandy czworga” oraz ich współpracowników, którzy kierowali Rewolucją Kulturalną, czy usuwanie tych zmarłych z cmentarza zasłużonych - zda- 
niem niektórych naszych dziennikarzy to drobiazg nie wart wzmianki. Podobnie jak odrzucenie ideologii maoizmu, wprowadzenie porządku prawnego, itd., czy nawet szaleńczy rozwój gospodarki rynkowej i zabiegi, by nowi miliarderzy zechcieli ogłaszać, że zapisują się do partii rządzącej, wciąż nazywającej się „,komunistyczną".

Rewolucja Kulturalna i wcześniejsze kampanie ideologiczne były jednak tylko epizodami, choć tragicznymi. W Chinach epoki Mao, między tymi paroksyzmami politycznymi, życie toczyło się dość normalnie. W pekińskiej popołudniówce ukazywały się zabawne felietony wykpiwające, choć w formie zawoalowanej, oficjalną ideologię. Niekiedy nawet pojawiały się metaforyczne drwiny z samego Przewodniczącego Mao. Najperfidniejsi wyśmiewali jego kult doprowadzając go do form absurdalnych. Nie daleko od Wzgórz Pachnących znajdowała się rezydencja Peng Dehuaia, byłego ministra obrony odsuniętego w 1959 r. za krytykę Mao. Przejeżdżając obok niej rowerem obserwowałem nieraz ruch limuzyn tam wjeżdżających i wyjeżdżających. W Rosji Sowieckiej za o wiele mniejsze polityczne występki dawno by już ziemię gryzł. Reżim Mao różnił się zasadniczo od stalinowskiego.

Ale wróćmy do ostatniego dnia. Wyszedłem na długi spacer wśród pól. Na rowerze jechał młody chłop z małą dziewczynką na ramie, z czerwonymi wstążeczkami w warkoczykach. Śpiewał na cały głos, z całej duszy, tak radośnie... A w pobliskim mieście szalała Rewolucja Kulturalna, i jeden po drugim przestawali mnie poznawać znajomi, a potem wielu z nich znikało. Później wiele razy zadawałem sobie pytanie, skąd brała się ta szczera radość owego chłopa. Czy była to może po prostu radość życia?

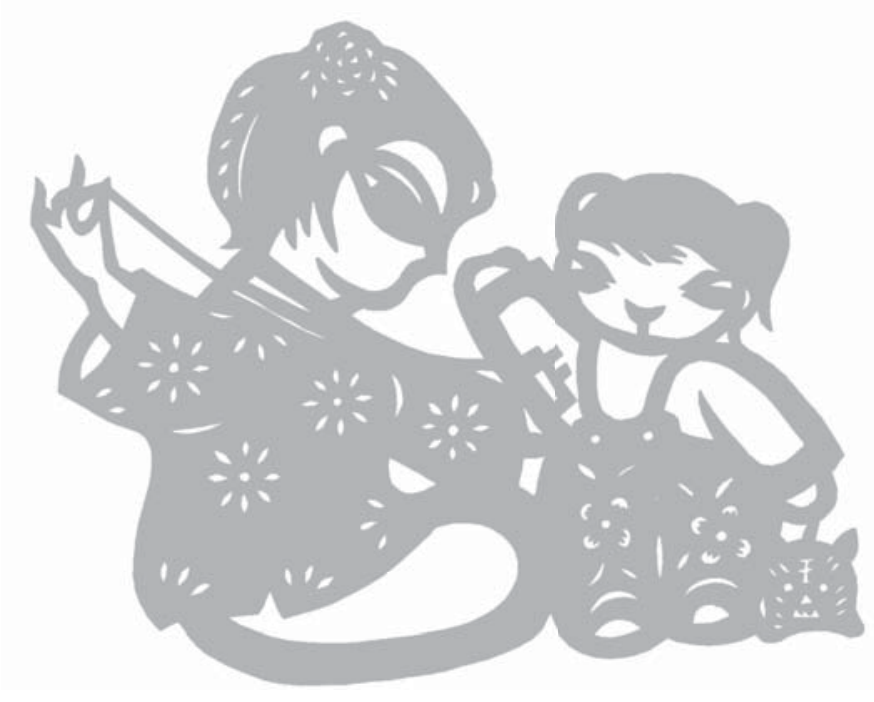

